\title{
EDITORIAL \\ The International Journal of Oncology: 30 years of progress
}

(1992-2021)

\section{DEMETRIOS A. SPANDIDOS}

Medical School, University of Crete, Heraklion, Greece

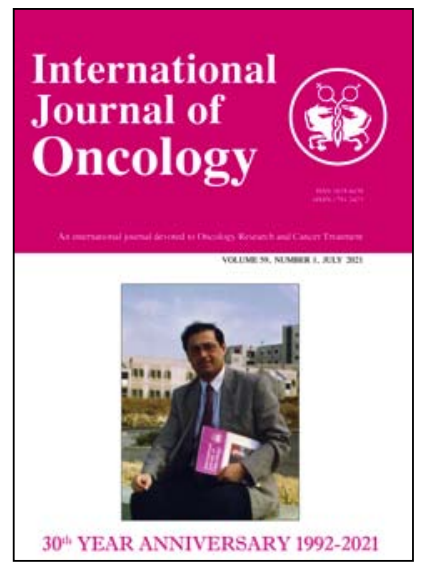

Table I. International Journal of Oncology (1992-June 2021).

\begin{tabular}{|c|c|}
\hline Country & No. of articles (\% total) \\
\hline 1. USA & $2,514(22.7)$ \\
\hline 2. Japan & $2,421(21.9)$ \\
\hline 3. P.R. China & 1,061 \\
\hline 4. Germany & 854 \\
\hline 5. Italy & $669 \quad(6.0)$ \\
\hline 6. South Korea & $533 \quad(4.8)$ \\
\hline 7. UK & $437 \quad(3.9)$ \\
\hline 8. France & $317 \quad(2.9)$ \\
\hline 9. Sweden & $288 \quad(2.6)$ \\
\hline 10. Canada & $202 \quad(1.8)$ \\
\hline 11.Spain & 123 \\
\hline 12. Belgium & 110 \\
\hline 13. Taiwan R.O.C & 109 \\
\hline 14. Austria & 95 \\
\hline 15. Czech Republic & 94 \\
\hline 16. Switzerland & 91 \\
\hline 17. Greece & 85 \\
\hline 18. The Netherlands & 85 \\
\hline 19. Poland & 79 \\
\hline 20. Singapore & 74 \\
\hline 21. Israel & 72 \\
\hline 22. Norway & 71 \\
\hline 23. Australia & 68 \\
\hline 24. Hong Kong & 56 \\
\hline 25. Denmark & 52 \\
\hline 26. India & 43 \\
\hline 27. Brazil & 40 \\
\hline 28. Finland & 34 \\
\hline 29. Argentina & 28 \\
\hline 30. Chile & 26 \\
\hline 31. Mexico & 23 \\
\hline 32. Egypt & 22 \\
\hline 33. Hungary & 22 \\
\hline 34. Thailand & 22 \\
\hline 35. Saudi Arabia & 20 \\
\hline 36. Ireland & 19 \\
\hline 37. South Africa & 19 \\
\hline 38. Russia & 17 \\
\hline 39. Slovak Republic & 15 \\
\hline 40. Lebanon & 11 \\
\hline 41. Croatia & 9 \\
\hline 42. Turkey & 9 \\
\hline 43. Kuwait & 8 \\
\hline 44. Malaysia & 8 \\
\hline
\end{tabular}

We are hereby very pleased to announce that the International Journal of Oncology is now celebrating its 30th year of publication since the inaugural issue in 1992. During this time span of three decades, the journal has had the pleasure of publishing a variety of research articles and reviews submitted by authors from around the world, thus bringing to light new insight into the field of oncology. The International Journal of Oncology has always aimed to publish high quality research on oncology from a diversity of international contributors. This diversity is depicted in Table $I$ below, which presents the list of countries from which the articles have originated over the years. We would also like to take this opportunity to thank all the authors and reviewers who have contributed to the success of the journal over the years, and with their support, we look forward to an even brighter future.

Table I. Continued.

\begin{tabular}{|c|c|}
\hline Country & No. of articles \\
\hline 45. Portugal & 8 \\
\hline 46. Indonesia & 7 \\
\hline 47. Luxembourg & 6 \\
\hline 48. Tunisia & 6 \\
\hline 49. Estonia & 5 \\
\hline 50. Guatemala & 5 \\
\hline 51. Iceland & 5 \\
\hline 52. New Zealand & 5 \\
\hline 53. Romania & 5 \\
\hline 54. Slovenia & 5 \\
\hline 55. United Arab Emirates & 5 \\
\hline 56. Vietnam & 5 \\
\hline 57. Uruguay & 4 \\
\hline 58. Pakistan & 3 \\
\hline 59. Philippines & 3 \\
\hline 60. Cuba & 2 \\
\hline 61. Cyprus & 2 \\
\hline 62. Ethiopia & 2 \\
\hline 63. Guadeloupe & 2 \\
\hline 64. Iran & 2 \\
\hline 65. Lithuania & 2 \\
\hline 66. Qatar & 2 \\
\hline 67. Serbia & 2 \\
\hline 68. Syria & 2 \\
\hline 69. Tanzania & 2 \\
\hline 70. Ukraine & 2 \\
\hline 71. Venezouela & 2 \\
\hline 72. Armenia & 1 \\
\hline 73. Belarus & 1 \\
\hline 74. Burkina Faso & 1 \\
\hline 75. Colombia & 1 \\
\hline 76. Honduras & 1 \\
\hline 77. Iraq & 1 \\
\hline 78. Libya & 1 \\
\hline 79. Martinique & 1 \\
\hline 80. Morocco & 1 \\
\hline 81. Republic of Cameroon & 1 \\
\hline 82. Tajikistan & 1 \\
\hline 83. Yemen & 1 \\
\hline Total $^{\mathrm{a}}$ & 11,070 \\
\hline
\end{tabular}

aSome articles were published jointly with scientists from more than one country. The actual total number of articles is 9,331 . 
The most frequently cited publications are presented.

PUBLICATIONS

1. THE ANTI-MALARIAL ARTESUNATE IS ALSO ACTIVE AGAINST CANCER

CITATIONS

508

By: EFFERTH T, DUNSTAN H, SAUERBREY A, et al

Int J Oncol 18: 767-773, 2001

2. A NEW FLUOROMETRIC ASSAY FOR CYTOTOXICITY MEASUREMENTS IN VITRO

By: PAGE B, PAGE M, NOEL C

Int J Oncol 3: 473-476, 1993

3. TEA IN CHEMOPREVENTION OF CANCER: EPIDEMIOLOGIC AND

EXPERIMENTAL STUDIES (REVIEW)

By: KATIYAR SK, MUKHTAR H

Int J Oncol 8: 221-238, 1996

4. HUMAN FOX GENE FAMILY (REVIEW)

By: KATOH M, KATOH M

Int J Oncol 25: 1495-1500, 2004

5. APIGENIN AND CANCER CHEMOPREVENTION: PROGRESS, POTENTIAL

AND PROMISE (REVIEW)

By: PATEL D, SHUKLA S, GUPTA S

Int J Oncol 30: 233-245, 2007

6. REGULATION OF CELL CYCLE PROGRESSION AND APOPTOSIS BY THE

Ras/Raf/MEK/ERK PATHWAY (REVIEW)

By: CHANG FM, STEELMAN LS, SHELTON JG, et al

Int J Oncol 22: 469-480, 2003

7. CHEMORESISTANCE TO PACLITAXEL INDUCES EPITHELIAL-MESENCHYMAL TRANSITION AND ENHANCES METASTATIC POTENTIAL FOR EPITHELIAL OVARIAN CARCINOMA CELLS

By: KAJIYAMA H, SHIBATA K, TERAUCHI M, et al

Int J Oncol 31: 277-283, 2007

8. OVER- AND UNDER-EXPRESSED microRNAS IN HUMAN COLORECTAL CANCER

By: MOTOYAMA K, INOUE H, TAKATSUNO Y, et al

Int J Oncol 34: 1069-1075, 2009

9. CANCER CHEMOPREVENTION BY RESVERATROL: IN VITRO AND IN VIVO STUDIES AND THE UNDERLYING MECHANISMS (REVIEW)

By: AZIZ MH, KUMAR R, AHMAD N

Int J Oncol 23: 17-28, 2003

10. INDUCTION OF CELL CYCLE ARREST AND APOPTOSIS IN HUMAN

BREAST CANCER CELLS BY QUERCETIN

By: CHOI JA, KIM JY, LEE JY, et al

Int J Oncol 19: 837-844, 2001

11. ANTIPROLIFERATIVE EFFECT OF SYNTHETIC RESVERATROL ON HUMAN BREAST EPITHELIAL CELLS

By: MGBONYEBI OP, RUSSO J, RUSSO IH

Int J Oncol 12: 865-869, 1998

12. MALAT-1: A LONG NON-CODING RNA AND ITS IMPORTANT 3' END FUNCTIONAL MOTIF IN COLORECTAL CANCER METASTASIS

By: XU C, YANG M, TIAN J, et al

Int J Oncol 39: 169-175, 2011

13. CELL DEATH: APOPTOSIS VERSUS NECROSIS (REVIEW)

By: KANDUC D, MITTELMAN A, SERPICO R, et al

Int J Oncol 21: 165-170, 2002

14. DNA STRAND BREAKS OCCURRING DURING APOPTOSIS - THEIR EARLY

IN SITU DETECTION BY THE TERMINAL DEOXYNUCLEOTIDYL TRANSFERASE

AND NICK TRANSLATION ASSAYS AND PREVENTION BY SERINE PROTEASE INHIBITORS

By: GORCZYCA W, BRUNO S, DARZYNKIEWICZ RJ, et al

Int J Oncol 1: 639-648, 1992

15. FLAVOPIRIDOL (L86 8275; NSC 649890), A NEW KINASE INHIBITOR FOR TUMOR THERAPY

By: SEDLACEK HH, CZECH J, NAIK R, et al

Int J Oncol 9: 1143-1168, 1996

16. EXPRESSION AND EPITHELIAL CELL ADHESION MOLECULE IN CARCINOMA

CELLS PRESENT IN BLOOD AND PRIMARY AND METASTATIC TUMORS

By: RAO CG, CHIANESE D, DOYLE GV, et al

Int J Oncol 27: 49-57, 2005

17. TUMOR ASSOCIATED MACROPHAGES IN HUMAN PROSTATE CANCER: RELATION

TO CLINICOPATHOLOGICAL VARIABLES AND SURVIVAL

By: LISSBRANT IF, STATTIN P, WIKSTROM P, et al

Int J Oncol 17: 445-451, 2000

18. THE HMGA PROTEINS: A MYRIAD OF FUNCTIONS (REVIEW)

By: CLEYNEN I, VAN DE VEN WJM

Int J Oncol 32: 289-305, 2008

19. CIRCULATING microRNAs: NEW BIOMARKERS IN DIAGNOSIS, PROGNOSIS

AND TREATMENT OF CANCER (REVIEW)

By: ALLEGRA A, ALONCI A, CAMPO S, et al

Int J Oncol 41: 1897-1912, 2012

20. RADIATION-INDUCED AUTOPHAGY IS ASSOCIATED WITH LC3 AND ITS

INHIBITION SENSITIZES MALIGNANT GLIOMA CELLS

By: ITO H, DAIDO S, KANZAWA T, et al

Int J Oncol 26: 1401-1410, 2005

Data obtained from the Web of Science Clarivate Analytics 06/05/2021.

We hope that this historical retrospect will be of interest to all readers, and that together, we may look forward to an even more fulfilling future. 